\title{
EFEKTIFITAS PELAKSANAAN SUPERVISI AKADEMIK KEPALA SEKOLAH
}

\author{
Apriani Safitri, Mujiati \\ Universitas Muhammadiyah Kendari \\ aprianisafitri@umkendari.ac.id
}

\begin{abstract}
ABSTRAK
Supervisi akademik merupakan layanan bantuan yang diberikan kepala sekolah kepada guru-guru dalam upaya perbaikan proses pembelajaran. Kinerja guru memiliki kontribusi besar dalam proses pembelajaran karena gurulah yang secara langsung bersentuhan atau berhadapan dengan peserta didik, sehingga perlu ada pengawasan baik secara langsung mau pun tidak langsung oleh kepala sekolah melalui kegiatan supervisi akademik. Tujuan Penelitian ini adalah untuk mendeskripsikan efektifitas pelaksanaan supervisi akademik kepala sekolah pada SD Negeri yang berada pada lingkup Unit Pelaksana Teknis Daerah (UPTD) Kecamatan Palangga Selatan.

Jenis penelitan ini adalah penelitian kualitatif dengan pendekatan fenomenologi. Subjek penelitian yaitu Kepala UPTD Kecamatan Palangga Selatan, kepala sekolah dan guru pada SD Negeri yang berada pada lingkup Unit Pelaksana Teknis Daerah (UPTD) Kecamatan Palangga Selatan. Teknik pengumpulan data dilakukan dengan mengunakan tiga cara yaitu observasi non partisipan yang tidak terstruktur, wawancara mendalam, dan studi dokumentasi. Teknik analisis data yang digunakan yaitu dengan alur, yang meliputi reduksi data, penyajian data, dan tahap verifikasi. Pengujian keabsahan data dilakukan dengan pendekatan triangulasi.

Hasil penelitian menunjukan bahwa: efektifitas pelaksanaan supervisi akademik kepala sekolah pada SD Negeri lingkup UPTD Kecamatan Palangga Selatan dilihat dari: perencanaan, pelaksanaan dan tindak lanjut pelaksanaan supervisi akademik kepala sekolah telah dilaksanakan secara efektif yang dapat dilihat dari input, convertion dan output, yang dilakukan secara berkelanjutan dan sistematis yang dilaksanakan di dalam kelas dengan tujuan untuk meningkatkan profesionalitas guru dalam proses akademik.
\end{abstract}

Katakunci : Supervisi Akademik Kepala Sekolah

\section{ABSTRACT}

Academic supervision is a help service provided by the principal to teachers in improving learning process. Teacher's performance has a large contribution in the learning process because the teacher directly touches or confronts the students, so it needs to be supervised by the principal through academic supervision specifically. The aim of this study is to describe the effectiveness of the academic supervision of principals in public elementary schools, UPTD of South Palangga.

This research is classified as qualitative research using phenomenological approach. The research subjects are Head of the UPTD of South Palangga, principals and teachers at the Public Elementary School, UPTD of the South Palangga. Data collection techniques were carried out using three ways, namely unstructured non-participant observation, in-depth interviews, and documentation studies. Data analysis techniques used are flow, which includes data reduction, data presentation, and verification phase. Testing the validity of the data is done by triangulation approach.

The results reveal that the effectiveness of the academic supervision of principals in the State Elementary School, UPTD of South Palangga was seen from: planning, implementation and follow-up implementation of school principals' academic supervision effectively which can be seen from input, conversion and output, carried out sustainably and systematically carried out in the classroom with the aim of increasing teacher professionalism in the academic process.

Keywords: Principal Academic Supervision 


\section{PENDAHULUAN}

Kepala sekolah berperan sebagai supervisor. Dimana supervisor pendidikan didefinisikan sebagai proses pemberian layanan bantuan profesional kepada guru untuk meningkatkan kemampuannya dalam melaksanakan tugas-tugas pengelolaan proses pembelajaran secara efektif dan efisien. Di dalam Peraturan Menteri Pendidikan Nasional (Permendiknas) Nomor 13 Tahun 2007 tentang Standar Kepala Sekolah ditegaskan bahwa salah satu kompetensi yang harus dimiliki seorang kepala sekolah adalah kompetensi supervisi, antara lain; Kepala Sekolah dapat memiliki kompetensi merencanakan program supervisi akademik dalam rangka peningkatan profesionalisme guru, dan dapat melaksanakan supervisi akademik terhadap guru dengan menggunakan pendekatan dan teknik supervisi yang tepat, serta dapat menindaklanjuti hasil supervisi akademik terhadap guru dalam rangka peningkatan profesionalisme guru.

Pelaksanaan supervisi akademik oleh kepala sekolah di SD Negeri yang berada pada lingkup Unit Pelaksana Teknis Daerah (UPTD) Kecamatan Palangga Selatan, Kabupaten Konawe selatan diharapkan dapat memberi dampak terhadap terbentuknya sikap profesional guru. Sikap profesional guru merupakan hal yang amat penting dalam memelihara dan meningkatkan profesionalitas guru, karena selalu berpengaruh pada perilaku dan akitivitas keseharian guru. Perilaku profesional akan lebih diwujudkan dalam diri guru apabila institusi tempat ia bekerja perhatian lebih banyak pada pembinaan, pembentukan, dan pengembangan sikap professional guru.

SD Negeri yang berada pada lingkup Unit Pelaksana Teknis Daerah (UPTD) Kecamatan Palangga Selatan, Kabupaten Konawe Selatan, pelaksanaan supervisi akademik kepala sekolah belum terlaksana secara optimal. Hal ini dapat dilihat dari persiapan pelaksanaan supervisi akademik yang belum terencana dengan baik. Sebagai dampak pelaksanaan supervisi akademik tersebut adalah rendahnya kinerja guru khususnya dalam proses pembelajaran, terdapat beberapa guru yang melakukan proses pembelajaran tidak didukung perangkat pembelajaran yang lengkap seperti adanya guru yang melakukan pembelajaran tanpa dilengkapi dengan rencana pelaksanaan pembelajaran (RPP), penggunaan metode mengajar yang kurang variatif artinya lebih banyak guru menggunakan metode ceramah tanpa mengkombinasikan dengan metode yang lainnya sehingga proses pembelajaran cenderung membosankan serta penggunaan media pembelajaran yang jarang dilakukan bahkan ada beberapa guru yang hanya menggunakan buku 
paket sebagai sumber belajar, sehingga kepala sekolah perlu melakukan suatu perubahan dalam menyelesaikan permasalahan yang dialami oleh guru melalui kegiatan supervisi akademik. Supervisi akademik kepala sekolah tidak hanya dilakukan pada waktu-waktu tertentu tetapi supervisi akademik kepala sekolah harus dilakukan secara berkelanjutan sebagai upaya mendisiplinkan guru dalam merancang pembelajaran dan merangsang kreatifitas guru-guru dalam menggunakan metode serta memanfaatkan berbagai macam sumber belajar yang dapat merangsang tercapainya prestasi belajar siswa.

Menurut Mulyasa (2014: 107), supervisi merupakan suatu proses yang dirancang secara khusus untuk membantu para guru dan supervisor dalam mempelajari tugas sehari-hari di sekolah; agar dapat menggunakan pengetahuan dan kemampuannya untuk memberikan layanan yang lebih baik pada orang tua peserta didik dan sekolah, serta berupaya menjadikan sekolah sebagai masyarakat belajar yang lebih efektif. Dalam penjelasan UUSPN Tahun 1989 UUSPN Pasal 52 kata supervisi dimasukkan dalam rangkaian kegiatan supervisi, yaitu: pengawas lebih merupakan upaya untuk memberikan bimbingan supervisi, dorongan, dan pengayoman bagi satuan pendidikan yang bersangkutan yang diharapkan dapat meningkatkan mutu pendidikan maupun pelayanannya.

Tujuan supervisi akademik menurut Ametembun (Tim Dosen Administrasi Pendidikan, 2012: 316), menyebutkan bahwa tujuan supervisi pendidikan adalah untuk mengembangkan situasi belajar dan mengajar yang lebih baik antara lain merumuskan tujuan supervisi pendidikan dengan memperhatikan beberapa faktor dan sifat khusus, sehingga dapat membantu mencari dan menentukan kegiatan supervisi yang lebih efektif.

Pembelajaran yang baik akan tercipta apabila kepala sekolah memiliki supervisi akademik yang baik. Supervisi akademik kepala sekolah menurut Peraturan Menteri Pendidikan Nasional RI No. 13 Tahun 2007 tentang Standar Kepala Sekolah/Madrasah seperti tercantum dalam tabel 1.

Tabel 1. Indikator supervisi akademik

\begin{tabular}{|c|l|}
\hline $\begin{array}{c}\text { Dimensi } \\
\text { Kompetensi }\end{array}$ & $\begin{array}{c}\text { Indikator Supervisi } \\
\text { Akademik }\end{array}$ \\
\hline Supervisi & $\begin{array}{l}\text { Merencanakan } \\
\text { program supervise } \\
\text { akademik dalam } \\
\text { rangka peningkatan } \\
\text { profesionalisme guru }\end{array}$ \\
\hline & Melaksanakan \\
& supervisi akademik \\
& terhadap guru \\
& dengan \\
& menggunakan \\
& pendekatan dan \\
& teknik supervisi yang \\
& tepat \\
\hline
\end{tabular}




\begin{tabular}{|c|l|}
\hline $\begin{array}{c}\text { Dimensi } \\
\text { Kompetensi }\end{array}$ & \multicolumn{1}{|c|}{$\begin{array}{c}\text { Indikator Supervisi } \\
\text { Akademik }\end{array}$} \\
\hline & $\begin{array}{l}\text { Menindak lanjuti } \\
\text { hasil supervisi } \\
\text { akademik terhadap } \\
\text { guru dalam rangka } \\
\text { peningkatan } \\
\text { profesionalisme guru. }\end{array}$ \\
\hline
\end{tabular}

Tujuan dalam penelitian ini adalah untuk mengetahui efektifitas pelaksanaan supervisi akademik kepala sekolah pada SD Negeri Lingkup Unit Pelaksana Teknis Daerah (UPTD) Kecamatan Palangga Selatan, Kabupaten Konawe Selatan.

Jenis penelitian ini adalah penelitian kualitatif dengan pendekatan fenomenologi. Melalui pendekatan fenomenologi, peneliti mencoba mengamati dan menjelaskan serta mengungkap makna dari peristiwa-peristiwa atau fenomena lapangan supervisi akademik yang dilakukan kepala sekolah pada SD Negeri Lingkup Unit Pelaksana Teknis Daerah (UPTD) Kecamatan Palangga Selatan sebagai temuan penelitian.

Teknik pengumpulan data dalam penelitian ini dengan mengunakan tiga cara yaitu sebagai berikut:

a. Observasi non partisipan yang tidak terstruktur.

b. Wawancara mendalam. Teknik wawancara mendalam ini digunakan untuk menggali data yang bersumber dari Kepala UPTD Kecamatan Palangga Selatan dan Kepala SD Negeri pada Lingkup Unit Pelaksana Teknis Daerah
(UPTD) Kecamatan Palangga
Selatan, yang berhubungan
dengan tahapan dan prosedur
kebijakan yang ditempuh dalam
kegiatan supervisi akademik kepala sekolah. Selain itu pula digunakan untuk menggali data yang bersumber dari guru pada SD Negeri pada Lingkup Unit Pelaksana Teknis Daerah (UPTD) Kecamatan Palangga Selatan, Kabupaten Konawe Selatan sebagai yang disupervisi, sehingga dapat dideskripsikan hasil analisis model supervisi akademik kepala sekolah.

c. Studi dokumentasi yaitu dalam prosesnya, peneliti menggunakan alat teknologi handphone kamera untuk mendokumentasikan hasil pengumpulan data berupa foto kegiatan selama wawancara dan bukti-bukti dokumen yang telah diarsipkan berupa tahapan dan prosedur kebijakan yang ditempuh oleh Kepala UPTD Kecamatan Palangga Selatan dan Kepala SD Negeri pada Lingkup Unit Pelaksana Teknis Daerah (UPTD) Kecamatan Palangga Selatan dalam melaksanakan supervisi akademik oleh kepala sekolah.

\section{Teknik analisis yang} digunakan dalam penelitian ini, yaitu dilakukan dengan alur yang meliputi reduksi data, penyajian data, dan tahap verifikasi. Pengujian 
kredibilitas data dilakukan dengan pendekatan triangulasi.

\section{Pelaksanaan Supervisi Akademik Kepala Sekolah}

\section{a. Perencanaan Supervisi Akademik}

Perencanaan supervisi akademik kepala sekolah pada SD Negeri lingkup UPTD Kecamatan Palangga Selatan dilakukan dengan melibatkan guru, kegiatan perncanaan dilakukan dengan cara: (1) menentukan jadwal pelaksanaan yakni menyesuaikan dengan program kepala sekolah yang lain, (2) menentukan waktu pelaksanaan yakni perbulan, triwulan dan persemester, (3) menetukan sasaran kegiatan supervisi, meliputi perencanaan, pelaksanaan dan evaluasi proses pembelajaran guru di kelas (4) mempersiapkan perlengkapan berupa format penilaian dan format pelaporan.

Muslim (2013: 134-135) menyebutkan bahwa agar kegiatan supervisi yang dilakukan kepala sekolah sesuai dengan kebutuhan nyata, maka program kerja yang disusun harus realislitis dan dikembangkan berdasarkan kebutuhan setempat. Purwanto, (2014: 106-107) juga menjelaskan bahewa salah satu fungsi utama dan pertama yang menjadi tanggung jawab kepala sekolah adalah membuat atau penyusun perencanaan. Perencanaan merupakan salah satu syarat mutlak bagi setiap organisasi atau lembaga dan bagi setiap kegiatan, baik perseorangan maupun kelompok. Tanpa perencanaan, pelaksanaan suatu kegiatan akan mengalami kesulitan dan bahkan mungkin juga kegagalan.

Senada menurut Donni \& Rismi (2014 : 113), setiap tahun menjelang dimulai tahun ajaran baru, kepala sekolah hendaknya telah siap menyusun rencana yang akan dilaksanakan untuk tahun ajaran berikutnya. Kepala sekolah perlu menguasai perencanaan supervisi akademik sehingga ia perlu menguasai kompetensi perencanaan supervisi akademik dengan baik. Terhadap sejumlah prinsip yang perlu diperhatikan dalam perencanaan supervisi akademik.

Selain memahami penyusunan rencana, kepala sokolah juga merancng format laporan. Hal ini dilakukan untuk memberian laporan sebagai bukti yang bersifat transparan terhadap seluruh tugas yang telah dilaksanakan. Laporan kegiatan itu dibuat setiap pelaksanaan supervisi.

Laporan kegiatan itu perlu dibuat agar program kerja dapat dikontrol sekaligus sebagai pertanggungjawaban dari setiap kepala sekolah/pengawasan dalam melaksanakan kinerjanya. $\mathrm{Hal}$ ini sejalan dengan penjelasan 


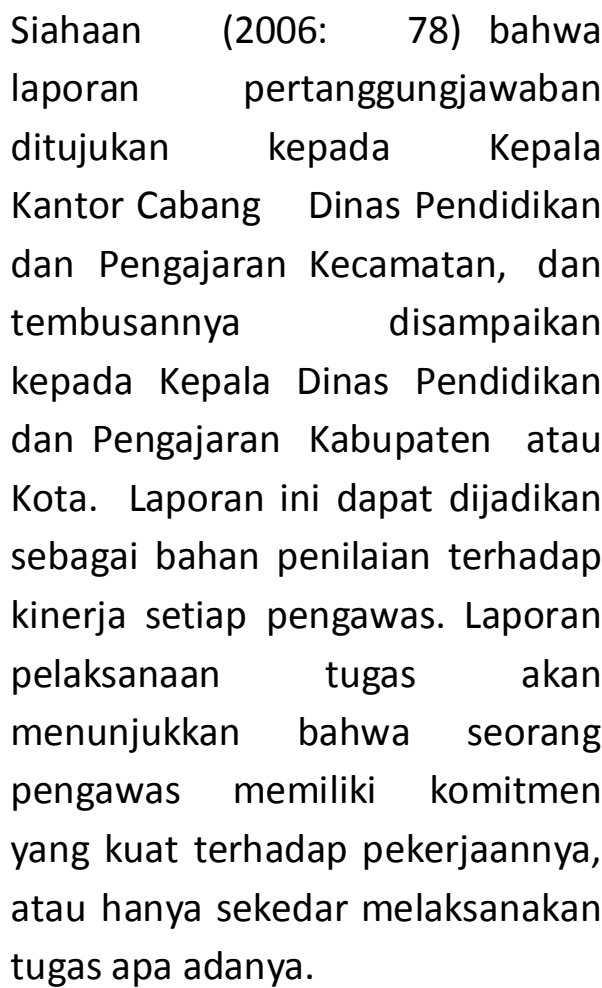

Berdasarkan pendapat di atas, maka dapat disimpulkan bahwa perencanaan supervisi akademik kepala sekolah pada SD Negeri lingkup UPTD Kecamatan Palangga Selatan, kegiatan perencanaan sangat penting untuk dilakukan baik kegiatan perseorangan maupun kelompok. Penyusunan rencana program supervisi kepala sekolah, disusun berdasarkan kebutuhan sekolah dan dilakukan secara bersamasama dengan guru. Tentunya penyusunan tersebut dilakukan di tahun ajaran baru, kepala sekolah dalam

\begin{abstract}
merencanakan supervisi
perlu menguasai kompetensi perencanaan supervisi akademik dengan baik. Selain itu kepala sekolah SD Negeri lingkup UPTD Kecamatan Palangga Selatan merancang sebuah format penilaian yang diperuntukan untuk menilai kinerja guru saat melaksanakan supervisi dan format laporan, karena kegitan supervisi yang dilakukan kepala sekolah akan dilaporkan pada kepala UPTD dan Dinas terkait dan juga dilaporkan pada sistem DAPODIK.
\end{abstract}

Semua

stakeholder

pendidikan dalam

menyelenggarakan pendidikan yang berkualitas ditentukan oleh semua pihak tidak terkecuali guru, kepala sekolah, kepala UPTD dan Dinas terkait. Dengan demikian dalam merancang perencanaan supervisi harus dilakukan dengan bekerja sama yakni Dinas Pendidikan merancang kebijakan-kebijakan yang wajib dilakukan oleh kepala sekolah dalam kegiatan supervisi dan memfasilitasi segala kegiatan kepala sekolah baik itu materil maupun moril guna peningkatan kompetensi kepala sekolah. Begitupun halnya kepala UPTD, untuk senantiasa mendukung program supervisi yang dirancang oleh kepala sekolah. Guru senantiasa bekerja sama dalam melaksanakan supervisi. 
Sehingga kerja sama tersebut dapat mewujudkan tercapainya pelaksanaan supervisi yang baik.

\section{b. Pelaksanaan Supervisi Akademik}

Teknik pelaksanaan supervisi akademik kepala sekolah pada SD Negeri lingkup UPTD Kecamatan Palangga Selatan dilakukan dalam dua teknik yakni (1) kunjungan kelas dan,

Observasi kelas. Kepala sekolah memantau guru dalam membuka pelajaran, menyajikan materi yang disesuaikan dengan motode dan media yang digunakan, membangun komunikasi dengan siswa melalui tanya jawab dan diskusi, melibatkan peserta didik dalam kegiatan pembelajaraan di dalam kelas dan penyusunan soal yang digunakan untuk menilai kemampuan peserta didik dalam menguasai materi dan di akhir pembelajaran kepala sekolah memberi contoh kepada guru tentang teknik pembelajaran yang menyenangkan bagi siswa. Memberi semangat kepada guru untuk lebih kreatif dan inovatif dalam melaksanakan proses pembelajaran.

Depdiknas (2003: 8), tujuan supervisi yang dilakukan mengacu pada tiga tujuan yakni:

1) Pengembangan

profesionalisme guru

2) Pengawasan kualitas pembelajaran guru di kelas
3) Menumbuhkan motivasi bagi guru untuk kreatif, nerinovasi dan melakukan pembelajaran yang menyenangkan.

Berdasarkan uraian di atas maka pelaksanaan supervisi akademik kepala sekolah pada SD Negeri lingkup UPTD Kecamatan Palangga Selatan bahwa supervisi terhadap guru-guru dilakukan oleh kepala sekolah, baik di dalam maupun di luar kelas dengan tujuan dapat mengembangkan profesional guru dalam melaksanakan proses pembelajaran Kualitas pembelajaran oleh guru ditentukan beberapa indikator, dan salah satunya adalah perangkat pembelajaran (RPP) jika perangkat ini tidak dirancang guru dengan baik maka akan berpengaruh pada pelaksanaan pembelajaran yang tidak terarah dan evaluasi hasil belajar siswa menurun. Selain itu kemampuan guru dalam mengajar dan menggunakan media juga ikut berperan didalam pencapaian pembelajaran. Dengan demikain, RPP, kemampuan guru dalam mengajar dan media sangat berperan penting dalam proses pembelajaran.

Dengan demikian, pelaksanaan supervisi akademik di SD Negeri lingkup UPTD Kecamatan Palangga Selatan, 
kepala sekolah mengharapkan guru untuk membuat RPP yang mencakup standar kompetensi, kompetensi dasar, indikator keberhasilan, dan materi ajar, penyajian materi yang menyenangkan, penggunaan metode yang tepat, adanya media sebagai pendukung proses pembelajaran dan tugas yang mampu mengukur seluruh kemampuan siswa baik itu pada penerapan kurikulum KTSP maupun KURTILAS.

\section{c. Tindak Lanjut}

Tindak lanjut pelaksanaan supervisi akademik kepala sekolah pada SD lingkup UPTD Kecamatan Palangga Selatan dilakukan dengan dua cara yakni: (1) secara langsung dilakukan dengan cara pertemuan individual, berkunjung antar kelas dan menilai diri sendiri, (2) pertemuan tidak langsung dilakukan dengan cara pelatihan, worksop, loka karya, KKG dan KKS. Sutisna (2006: 224), bahwa bantuan pembinaan kepada guru dapat diberikan melalui berbagai kegiatan seperti: kunjungan kelas, diskusi kelompok, loka karya, seminar, demonstrasi mengajar, bacaan profesional, kunjungan antar kelas, atau melalui partisipasi staf dalam pengembangan kurikulum dan instruksional atau kegiatan profesi lainnya. Suhardan (2010: 178), menyebutkan bahwa pada dasarnya pengawasan profesional kepala sekolah bertujuan untuk menciptakan situasi pembelajaran kearah yang lebih baik, terutama membantu guru sebagai tenaga pelaksana kegiatan mengajar yang berpengaruh terhadap proses belajar.

Menurut Donni \& Rismi, (2014: 117-118) beberapa cara yang dapat dilakukan kepala sekolah dalam membina untuk meningkatkan proses pembelajaran dalam : (1) menggunakan secara efektif petunjuk bagi guru dan bahan pembantu guru lainnya. (2) mengunakan buku teks secara efektif. (3) Menggunakan praktek pembelajaran yang efektif yang dapat mereka pelajari selama pelatihan. (4) Mengembangkan teknik pembelajaran yang telah mereka miliki. Selain itu, Sahertian (2008:27) menyatakan bahwa objek supervisi ialah perbaikan situasi belajar mengajar dalam arti yang luas, menyebutkan empat objek supervisi yaitu: (1) pembinaan dan pengembangan kurikulum; perbaikan proses pembelajaran; (3) pemberdayaan sumber daya guru dan staf; dan (4) pemeliharaan dan perawatan moral serta semangat kerja guru. Berdasarkan uraian di atas maka tindak lanjut pelaksanaan supervisi akademik kepala sekolah pada SD Negeri lingkup UPTD Kecamatan Palangga Selatan 
bahwa bentuk pembinaan yang diberikan sebagai bentuk penyelesaian masalah yang ditemukan saat pelaksanaan supervisi akademik yang dilakukan kepala sekolah.

Bentuk pembinaan tersebut dilakukan secara personal dimana kepala sekolah mengadakan pertemuan secara individual membahas segala kemampuan dan kekurangan guru dalam melakukan pembelajaran tentunya komunikasi yang dibangun berdasarkan musyawarah tidak menginterogasi atau menggurui. Hal dilakukan untuk member rasa nyaman bagi guru. Bentuk pembinaan yang lain adalah dalam bentuk pelatihan, seminar, dan workshop dimana guru dilibatkan didalam kegiatan tersebut, selain kegiatan tersebut KKG merupakan wadah bagi guru untuk banyak belajar mengenai banyak hal tentang proses pembelajaran.

Dengan demikian kegiatan pembinaan harus dilakukan secara berkelanjutan dan sistematis. Dengan tema yang berkaitan dengan permasalahan yang di alami oleh guru. Saat ini pemerintah terfokus pada pelatihan dan workshop penerapan KURTILAS sementara para guru SD Negeri lingkup UPTD Kecamatan Palangga Selatan memiliki permasalahan yang beragam. Masih banyak guru yang belum mampu menerapkan beberapa media dalam pembelajarannya utamanya adalah media teknologi, minimal guru diberikan bantuan fasilitas labtop dan guru diberikan pelatihan bagaimana membuat power pointyang menarik, menggunakan video atau film dalam pembelajaran dengan demikian pembelajaran akan efektif, inovatif dan menyenangkan. Alur pelaksanaan supervisi akademik kepala sekolah dapat dilihat dalam gambar berikut:

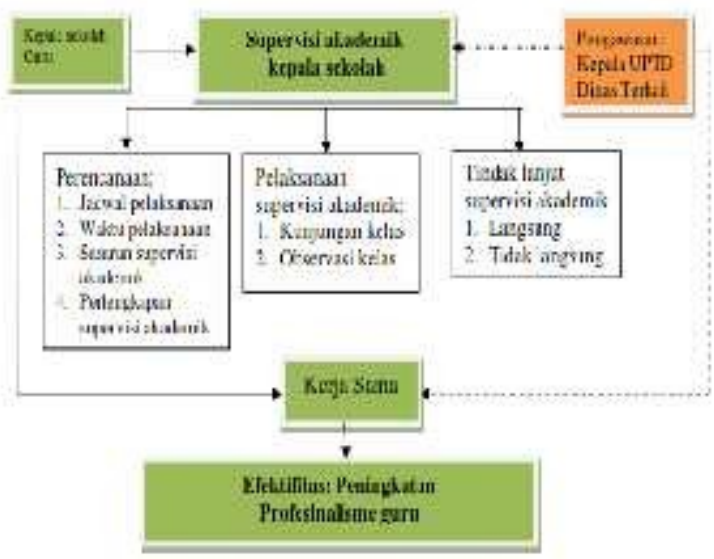

Gambar 2. Alur pelaksanaan supervisi akademik kepala sekolah

Efektifitas

Pelaksanaan

Supervisi Akademik Kepala Sekolah

Efektifitas pelaksanaan supervisi akdemik kepala sekolah pada SD Negeri lingkup UPTD Kecamatan Palangga Selatan telah berjalan efektif dilihat dari input, conversion dan output. Input berupa guru, jadwal, waktu, sasaran dan perlengkapan. Conversion berupa 
kemampuan kepala sekolah dalam melaksanakan supervisi akademik. Output yang dihasilkan dalam kegiatan pelaksanaan supervisi akademik adalah peningkatan profesionalisme guru dalam perencanaan pembelajaran, pelaksanaan di dalam kelas dan evaluasi hasil belajar siswa.

Menurut Jones, (Imelda, 2016) bahwa pencapaian hasil efektifitas yang dilakukan oleh suatu organisasi terdiri dari tiga tahap, yakni input (masukan), conversion (perubahan), dan output (hasil). Input meliputi semua sumber yang dimiliki, informasi dan pengetahuan, bahan-bahan mentah serta modal. Pada tahap input, tingkat efisiensi sumber daya yang dimiliki sangat menentukan kemampuan yang dimiliki. Tahap conversion ditentukan oleh kemampuan organisasi untuk memanfaatkan sumber daya yang dimiliki, manajemen dan penggunaan teknologi agar dapat menghasilkan nilai. Tahap ini, tingkat keahlian sumber daya manusia dan daya tanggap organisasi terhadap perubahan lingkungan sangat menentukan tingkat produktifitasnya. Sedangkan dalam tahap output pelayanan yang diberikan merupakan hasil dari penggunan teknologi dan keahlian sumber daya manusia. Imelda dkk, (2016) dalam kaitannya dengan pelaksanaan supervisi, efektivitas memiliki ukuran yaitu:
1) Jumlah hasil yang dapat dikeluarkan, artinya hasil tersebut berupa kuantitas atau bentuk fisik dari organisasi, perorangan atau kegiatan. Hasil dimaksud dapat dilihat dari perbandingan antara masukan dengan keluaran.

2) Tingkat kepuasan yang diperoleh, artinya ukuran dalam efektivitas ini dapat kuantitatif (berdasarkan pada mutu).

3) Produk kreatif, artinya penciptaan hubungannya kondisi yang kondusif dengan dunia kerja yang nantinya dapatmenumbuhkan kreatifitas dan kemampuan.

Menurut Kurniawan (2005:109), “Efektivitas adalah kemampuan melaksanakan tugas, fungsi (operasi kegiatan program atau misi) dari pada suatu organisasi atau sejenisnya yang tidak adanya tekanan atau ketegangan diantara pelaksanaannya".

$$
\text { Adapun }
$$
efektifitas pelaksananaan supervisi akademik kepala sekolah dapat digambarkan sebagai berikut: 


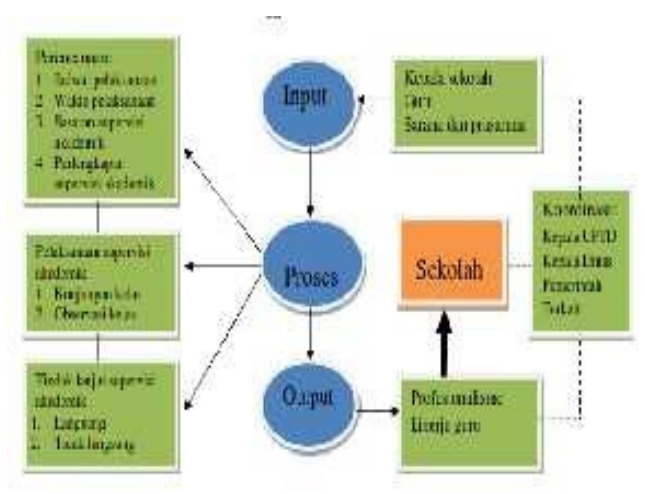

Gambar 2. Efektifitas pelaksanaan supervisi akademik kepala sekolah.

\section{SIMPULAN}

Berdasarkan hasil penelitian dan pembahasan dalam penelitian yang telah peneliti laksanakan, maka dapat disimpulkan bahwa: efektifitas pelaksanaan supervisi akdemik kepala sekolah pada SD Negeri lingkup UPTD Kecamatan Palangga Selatan dilihat dari: 1) perencanaan supervisi akademik kepala sekolah dilaksanakan dengan melibatkan semua stakeholder pendidikan dalam menyelenggarakan pendidikan yang berkualitas ditentukan oleh semua pihak tidak terkecuali guru, kepala sekolah, kepala UPTD dan Dinas terkait. Sehingga dalam merancang perencanaan supervisi harus dilakukan dengan bekerja sama. 2) dalam pelaksanaan supervisi akademik kepala sekolah, guru diharapkan untuk membuat RPP yang mencakup standar kompetensi, kompetensi dasar, indikator keberhasilan, dan materi ajar, penyajian materi yang menyenangkan, penggunaan metode yang tepat, adanya media sebagai pendukung proses pembelajaran dan tugas yang mampu mengukur seluruh kemampuan siswa baik itu pada penerapan kurikulum KTSP maupun KURTILAS. 3) tindak lanjut pelaksanaan supervisi akademik kepala sekolah dalam bentuk pembinaan harus dilakukan secara berkelanjutan dan sistematis dengan tema yang berkaitan dengan permasalahan yang di alami oleh guru. Dengan demikian, kegiatan supervisi mampu memberikan guru sebuah inovasi dalam pembelajaran, dan memberikan ruang kepada guru untuk berkreatifitas.

\section{UCAPAN TERIMAKASIH}

Dengan kerendahan hati tim peneliti menyampaikan terima kasih kepada Kementrian RISTEKDIKTI yang telah mendanai penelitian ini, LPPM UMK, dan semua pihak yang tidak dapat disebutkan satu per satu yang telah banyak membantu terselesaikannya proses penelitian ini.

\section{DAFTAR PUSTAKA}

Donni, Juni Priansa dan Rismi, M Somad. (2014). Manajemen Supervisi dan Kepemimpinan Kepala Sekolah. Alfabeta, Bandung.

Departemen Pendidikan Nasional., 2003, Undang-Undang Nomor 20 Tahun 2003 tentang Sistem Pendidikan Nasional. Jakarta: Depdiknas. 
Imelda dkk. (2016). Efektifitas Pelakasnaan Supervisi Mata Pelajaran oleh Pengawas Sekolah dalam Perbaikan Kompetensi Pedagogik. Jurnal Kultur Demokrasi.

Kurniawan, Agung. (2005). Transformasi Pelayanan Publik. Yogyakarta: Penerbit Pembaharuan.

Misnawati. (2016). Jurnal IImu Administrasi Negara: Efektifitas Kerja Pegawai Negeri Sipil Kantor Kecamatan Marangkayu Kabupaten Kutai Kartanegara. Volume 4 Nomor 1 Halaman 25922604.

Mulyasa, E. (2014). Menjadi Kepala Sekolah Profesional. Bandung: PT. Remaja Rosdakarya.

Muslim, Sri Banun (2010). Supervisi Pendidikan Meningkatkan Kualitas Profesionalisme Guru. Bandung: Alfabeta. Peraturan Menteri Pendidikan Nasional Republik Indonesia Nomor 13 tahun 2007 tentang Standar Kepala Sekolah/Madrasah. Jakarta: BSNP.

Purwanto, Ngalim (2014). Administrasi dan Supervisi pendidikan, PT Remaja Rosdakarya. Bandung.

Siahaan, Amiruddin dkk. (2006). Manajemen Pengawas Pendidikan. Jakarta: Quantum Teaching.

Sutisna, Oteng. (2007). Administrasi Pendidikan Dasar Teoritis dan Praktek Profesional, Bandung: Angkasa.
Sahertian, Piet A. (2010). Konsep Dasar dan Teknik Supervisi Pendidikan dalam Rangka Pengembangan Sumber Daya Manusia, Jakarta: Rineka Cipta.

Suhardan, Dadang. (2010). Supervisi Professional (layanan dalam Meningkatkan Pengajaran di Era Otonomi Daerah). Bandung: Alfabeta.

Tim Dosen Administrasi Pendidikan. (2012). Manajemen Pendidikan. Universitas Pendidikan Indonesia. Bandung. 